\title{
Conductivity Anomalies in Central Europe
}

\author{
Anne Neska ${ }^{1}$
}

Received: 5 December 2014/ Accepted: 3 November 2015/Published online: 12 November 2015

(C) The Author(s) 2015. This article is published with open access at Springerlink.com

\begin{abstract}
This paper is a review of studies which, by applying the magnetotelluric, geomagnetic deep sounding, and magnetovariational sounding methods (the latter refers to usage of the horizontal magnetic tensor), investigate Central Europe for zones of enhanced electrical conductivity. The study areas comprise the region of the Trans-European Suture Zone (i.e. the south Baltic region and Poland), the North German Basin, the German and Czech Variscides, the Pannonian Basin (Hungary), and the Polish, Slovakian, Ukrainian, and Romanian Carpathians. This part of the world is well investigated in terms of data coverage and of the density of published studies, whereas the certainty that the results lead to comprehensive interpretations varies within the reviewed literature. A comparison of spatially coincident or adjacent studies reveals the important role that the data coverage of a distinct conductivity anomaly plays for the consistency of results. The encountered conductivity anomalies are understood as linked to basin sediments, asthenospheric upwelling, large differences in lithospheric age, and-this concerns most of them, which all concentrate in the middle crust - tectonic boundaries that developed during all mountain building phases that have taken place on the continent.
\end{abstract}

Keywords Carpathian Conductivity Anomaly · North German-Polish Conductivity Anomaly · Trans-European Suture Zone · Magnetotellurics · Orogeny · Electromagnetic induction studies in Europe

\section{Introduction}

Central Europe is a relatively small region geologically, geographically, and tectonically on a global scale. It covers not much more than one million square kilometres of the Earth's surface; in detail, the number depends on how this part of the world is defined exactly.

Anne Neska

anne@igf.edu.pl

1 Institute of Geophysics, Polish Academy of Sciences, ul. Księcia Janusza 64, 01-452 Warsaw, Poland 
Central Europe is not known either for strong earthquakes or for actual, ongoing volcanism. Some examples of current tectonic activity can be found in this region (or close to it, depending on its exact definition, i.e. the rifting of the Rhine Graben in SW Germany and subduction beneath the Vrancea region in SE Romania), but these examples are rather exceptions to the rule that no dramatic tectonic activity takes places in the middle of the European continent. Furthermore, Central Europe is densely populated and highly industrialised. Taking into account that first, crustal and lithospheric-scale electrical conductivity anomalies are mainly results of magnetotellurics, a passive sounding method that suffers from man-made electromagnetic noise, and second, its targets are often linked to active tectonics due to its sensitivity to high rock temperature and partial melting, it would appear not very likely that anything interesting can be told under the title of this review.

It is due to history (both the one of the continent and the one of its inhabitants) that this assumption is misleading. The turbulent tectonic history undergone by parts of Europe, which has left imprints in the electrical conductivity images of the subsurface, is treated in the next section. From a cultural point of view, that Central Europe consists of a number of countries plays a significant role. Each of them has at least one geophysical institute with a working group linked to geoelectromagnetism, many of them have more than one, and Germany has even a double-digit number of such research bases. Another example to illustrate the density of scientific infrastructure is geomagnetic observatories. They are linked to magnetotellurics by a partly identical instrumentation (e.g., fluxgate magnetometers) and to geomagnetic depth sounding by the fact that this method was invented as a side effect of geomagnetic observation, a thread that will be returned to in Sect. 2. The number of geomagnetic observatories organised in the international INTERMAGNET network that are situated in the region considered here is 13 . This is more than in any comparably sized area of the world. As a result, many scientists have dedicated their work to natural source electromagnetic induction research, and they have done it in a way that is well distributed over the whole Central Europe. Among them are pioneers of the method, such as Peter Weidelt (1938-2009), Ulrich Schmucker (1930-2008), and Horst Wiese (1922-1972) whose name is connected to an important quantity, the induction arrow, used by most practitioners of the magnetotelluric method today.

Although the mere presence of geophysical institutes does not necessarily ensure that their research focuses on the regions on their own doorsteps, the availability of infrastructure and qualified manpower has resulted in good data coverage of this part of the continent. Only very few regions of Central Europe are white spots on the map in the sense that they have never experienced a magnetotelluric measurement, and these few are not large in geographical size. This certainly does not mean that there does not remain future work or open questions but, in fact, that the scientific output about this area in the domain of conductivity anomalies is considerable. Hence, comprehensive material exists that can be summarised under the focus of this review and told about in a number of interesting threads.

To define the scope of this work, it is necessary to consider the term "conductivity anomaly". This term is frequently used among practitioners of the electromagnetic induction methods in the sense that "conductivity" refers to enhanced electric conductivity values and "anomaly" describes a locally or regionally limited phenomenon, which is distinguishable from some "normal", one-dimensional surrounding (where the "normal" structure on both sides of an anomaly may be different, Schmucker 1970a). Thereby, it is important to note that this distinction is based on transfer functions (usually induction arrows), which emerge at a stage of the magnetotelluric working process before the modelling or inversion. I want to point this out very clearly: Data containing such an 
anomaly require at least a two-dimensional (if not a three-dimensional) inversion as they are locally inhomogeneous, or caused by lateral conductivity contrasts, respectively. The first attempts to establish two-dimensional modelling (e.g., Jupp and Vozoff 1977; Weidelt 1978) were published definitely later than several early mentions of conductivity anomalies, e.g., the North German-Polish one (Schmucker 1959), the Eskdalemuir one (Osemeikhian and Everett 1968), and the Carpathian one (Rokityansky 1972). From this follows that speaking of a certain conductivity anomaly is not bound to the availability of a model of the depth and spatial distribution and level of the underlying conductivity (or resistivity) values. This means that the term "conductivity anomaly" is not really helpful for potential users of the results of magnetotelluric studies, who would like to interpret a model in terms of petrology, geology, or tectonics. The strength and value of that term lie elsewhere.

A conductivity anomaly describes a first-order effect in magnetotelluric and geomagnetic transfer functions; it means that strong secondary (induced) magnetic fields are encountered, i.e. the phenomenon that the induction methods are designed for and react most sensitively to. This means that within a data set is something that is so fundamental that it usually can be seen and qualitatively assessed already during field work. This is important if one takes into account that magnetotelluric inversion in general suffers from the fact that it is an ill-posed problem (Berdichevsky and Dmitriev 2002). The core of this difficulty is that data may be nearly identical even for a number of relatively different underlying conductivity structures. Here, conductivity anomalies can have a certain remedial effect: Conductivity anomalies are very robust features under inversion because the variation of data over a certain lateral distance provides constraints. This does not make the magnetotelluric inverse problem less ill-posed, but if a whole anomalous area and anomalous frequency range are covered by data, the models obtained from them will provide at least one unquestionable, well-resolved, well-constrained, and most probably prominent well-conducting signature that causes this anomaly in the data. Hence, although the term "conductivity anomaly" per se does not enable an interpretation yet, it is a promise. A data set comprising a full anomaly has the potential to result in a model that allows for one of the most authoritative statements the electromagnetic induction methods are able to make: a good conductor exists at a certain location and depth, along with information on its (at least top-side) geometry.

Not in every case this distinction between the term "conductivity anomaly" and a model of it that invites to interpretation may appear necessary. In the recent past, studies were published that deliver both things at the same time, e.g., Brasse et al. (2002, for a case from South America). Hence, one may wonder why bother (especially non-magnetotelluric) readers with that anomaly term if a more practical one, that of a distinct conductor, can be offered. However, for Central Europe it is justified to adhere to the first one for a number of reasons: (a) for one of the regional anomalies, the Göttingen D-Anomaly, only this term exists; a full model has not been presented so far. (b) Although nowadays twodimensional models exist that explain the North German-Polish and the Carpathian Conductivity Anomalies, these names, which were coined more than four decades ago, remained in scientific discourse and they are encountered in the current literature (e.g., Schäfer et al. 2011; Jankowski et al. 2008). (c) Figure 1 shows that the large anomalies mentioned in (b) hold many countries of Central Europe together like braces. Following their course, one can get narratives leading to almost every location of an electromagnetic induction study in the middle of the continent.

I will consider results of studies from the domain of classical magnetotellurics, geomagnetic depth sounding, and magnetovariational (i.e. horizontal magnetic) sounding in 
the long period and broad-band frequency ranges. Neither induction studies carried out by means of active electromagnetic methods nor those investigating near-surface targets (i.e. top kilometre) are within my scope. Likewise, deep (having their focus beyond the crust) induction studies and those utilising natural electromagnetic field variations but leaving basic assumptions of magnetotellurics are omitted here; a review of such works for the region of interest can be found in Korja (2007) and in Semenov (2014).

Regarding the time frame of the scientific papers reviewed here, it has been my task to consider recent work. Therefore, most of the cited papers are published within the last 15 years (1999-2014). However, a number of references are from earlier times, partly because of their historical importance and partly because of the lack of newer work for some of the locations.

Finally, the toponym "Central Europe" has to be defined for the purpose of this paper. Of course, a glance on a map (e.g. in Fig. 1) will provide some idea of what Europe's central part is. However, an exact definition of the term in a geographical, political, or any other sense, does not formally exist. Hence, I have taken the liberty to select regions of interest also according to the availability of magnetotelluric studies for them, and following the desire for not cutting off the description of a conductivity anomaly at a frontier. As a result of this, some countries that intuitively belong to Central Europe (like Austria and Switzerland) are underrepresented here and some that do not are considered. This work

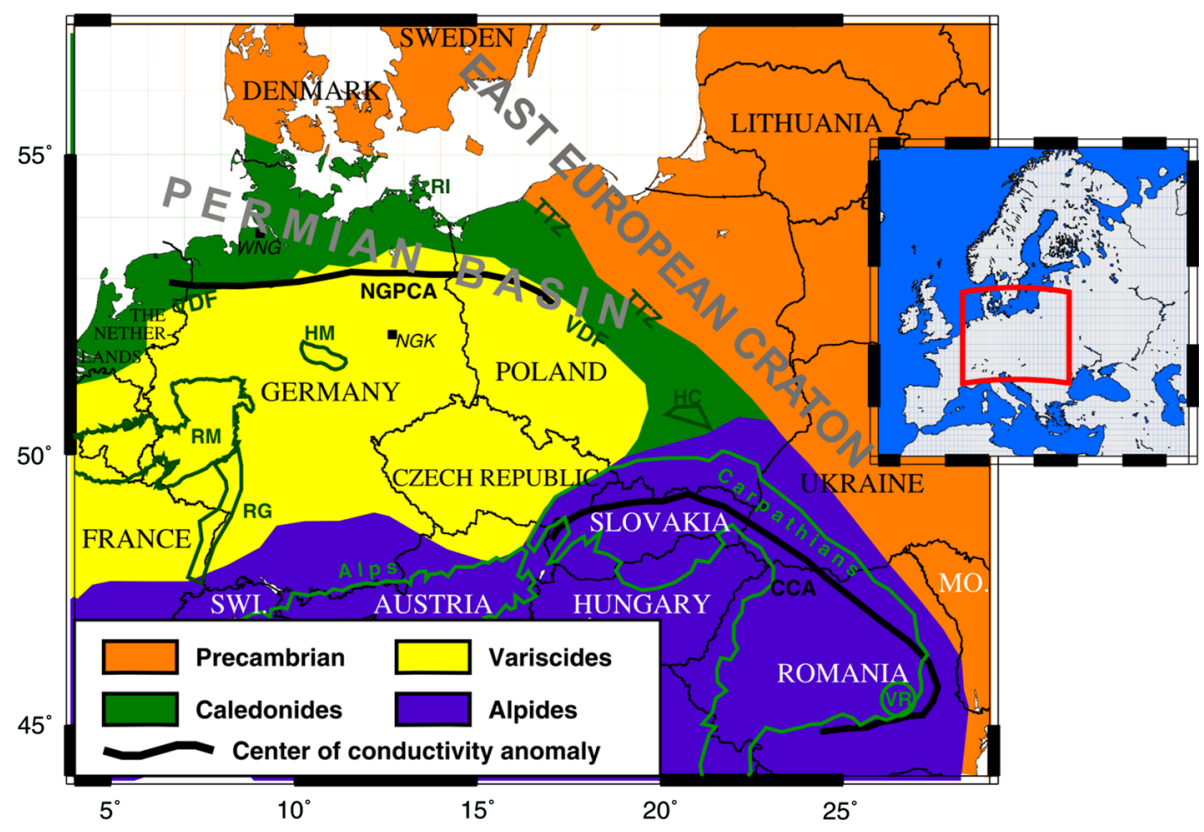

Fig. 1 Tectonic overview of Central Europe. Tectonic boundaries after Berthelsen (1992), simplified, for the Ukraine modified after Gordienko et al. (2011), Permian Basin after van Wees et al. (2000). Abbreviations in alphabetical order: $C C A$ Carpathian Conductivity Anomaly, $H C$ Holy Cross Mountains, $H M$ Harz Mountains, MO Moldova, NGPCA North German-Polish conductivity anomaly, NGK Niemegk observatory, $R G$ Rhine Graben, $R I$ Rügen Island, $R M$ Rhenish Massif, SWI Switzerland, TTZ TeisseyreTornquist Zone, VDF Variscan Deformation Front, VR Vrancea region (after Sperner et al. 2001), WNG Wingst observatory. Anomaly centres are taken from positions of real induction arrow reversals, for the NGPCA after Horejschi (2002) and Neska et al. (2008), for the CCA after Nowożyński (2012) 
reviews studies from Austria, the Czech Republic, Denmark, Germany, Hungary, Poland, Romania, Slovakia, Sweden, Switzerland, and the Ukraine.

This paper is organised according to the main tectonic units of Central Europe such that one section is dedicated to studies on each the Precambrian-Caledonian, the Variscan, and the Alpine basement, preceded by an overview of these units.

\section{Tectonic Overview}

This overview serves as an introduction and approximate classification of tectonic areas that will be used in the following sections as settings of induction studies. It is not its purpose to be complete or detailed in terms of tectonics itself; such overviews can be found elsewhere (e.g., Gee and Stephenson 2006 and citations therein).

Central Europe consists of four main tectonic units, which are named after the mountain building phases when the underlying rocks were subjected to tectonic deformation for the last time. These units are illustrated in Fig. 1, where the boundaries between them follow roughly Berthelsen (1992). The oldest one is the East European Craton (EEC), which is of Precambrian age. Regarding the regions considered here, it comprises NE Poland, Southern Scandinavia, Moldova, and all of the West Ukraine except for the Carpathians and Transcarpathians.

The next unit is named after the remnants of the Caledonian orogeny, which extend from Denmark over North Germany and NW Poland to Central Poland. These rocks were formed during the Late Ordovician, when the former continent of Baltica collided with the Avalonian microcontinent subsequent to the Tornquist Sea between them being consumed by subduction. The closure of this ocean has left a suture zone that is called the SorgenfreiTornquist Zone (STZ) in its Western part, the Teisseyre-Tornquist Zone (TTZ) in its Eastern part, and the Trans-European Suture Zone as a whole. In contrast to the Scandinavian and Scottish-Irish ones, ${ }^{1}$ the Central European Caledonides barely outcrop. Most of the rocks of this orogen are hidden beneath the sedimentary overburden of the Permian Basin that extends from the North Sea to NW Poland. Only in the South-Central Polish Holy Cross Mountains are such formations accessible at surface.

The Variscan (or Hercynian) orogeny took place during the Carboniferous. This phase was characterised by the collision of Euramerica (see footnote 1) with Gondwana, a process accompanied by the closure of the Rheic Ocean and resulting in the creation of the supercontinent Pangea. In today's Central Europe, vast areas of Central Germany, SW Poland, and most parts of the Czech Republic are composed of Variscan formations. However, the northern rim of them, referred to as the Variscan (Deformation) Front, is hidden beneath the younger Permian Basin, just like the Caledonides are. The northernmost visible representatives of the German Variscides are the Rhenish Massif and the Harz Mountains. The Variscan Mountains were subsequently subjected to fault block tectonics during Alpine orogeny. The largest continuous unit of them is the Bohemian Massif, which comprises most of the territory of the Czech Republic, whereas especially the German "Mittelgebirge" form complex horst-and-graben and tilted-type block mountain structures.

\footnotetext{
1 These West- and North-European Caledonides were formed during the Silurian due to collision with the Laurentia continent under closure of the Iapetus Ocean. The resulting continent is called Euramerica, Laurussia, or Old Red Continent.
} 
From the Jurassic onwards, Pangea began to break up into a number of continental plates. During the Cretaceous, the African Plate to the South and the Eurasian ${ }^{2}$ Plate to the North moved against each other with consumption of the Tethys Sea that divided them. This process led to the latest mountain building phase, the Alpine orogeny. With regard to the Alpides, Central Europe contains parts of the Alps itself (i.e. the highest mountains of today's inner Europe ${ }^{3}$ ) as well as parts of the Carpathians. ${ }^{4}$ Since the investigation of the Carpathians by means of electromagnetic induction studies is much more advanced than that of the Alps, I concentrate the following considerations on them. However, it should be noted that the Eastern Alps and the Western Carpathians are relatively similar to each other. According to Csontos and Vörös (2004), the geologic units occurring and the tectonic processes having taken place in both orogens correlate to a large extent.

The Carpathian range is extraordinarily bent. On a physical map, it has nearly the shape of a mirror-inverted letter C. This makes it advisable to speak about Inner and Outer Carpathians. Enclosed by this arc is situated the Pannonian Basin, which spatially coincides approximately with Hungary. Along the arc, the Carpathians can be divided into the Western (loosely speaking on Polish/Slovakian territory), Eastern (roughly Ukrainian), and Southern (situated in Romania) Carpathians. Csontos and Vörös (2004) draw a detailed picture of the genesis of this mountain belt and the enclosed basin. Some of its features that will be relevant in the following considerations are reproduced here. A number of terranes were situated in between the continental plates of Africa and Eurasia. Some of them were of African origin, some of Eurasian origin, and they were of rather different size. They divided the Tethys Sea into a number of partly quite narrow oceanic units. The Carpathians developed as two separate oroclinal bends that were formed concurrently, but in rather different positions and orientations than the contemporary picture suggests, due to subduction of oceanic crust under those terranes. Thereby the downgoing slabs came from the "outer" sides of bends, i.e. Eurasian oceanic crust was subducted under crust of the terranes. Evidence for the subduction processes is the huge areas of flysch nappes covering all outer margins of the Carpathians, the presence of volcanic rocks and those subjected to high-pressure metamorphism in their central parts, and the seismic region of Vrancea (Fig. 1), which has been interpreted as the last stage of subduction at the last location of ongoing subduction in the Carpathians (Sperner et al. 2001). In the Western Carpathians, the final suture zone is marked by the narrow area of the Pieniny Klippen Belt. Both microcontinents containing the Carpathian range had found their relative orientations and their positions next to each other by the middle of the Cretaceous. In the Eocene, the Tethys Ocean closed and the "Carpathian terranes" were pushed against the Eurasian Plate.

\section{The Caledonides and the Precambrian Craton: Tectonic Borders Buried Beneath Kilometres of Sediments}

The northernmost part of Central Europe hosts a famous conductivity anomaly which is of special historical importance for the development of geophysical induction methods. It is the North German-Polish conductivity anomaly (Fig. 1). Its centre runs approximately along

\footnotetext{
2 More correctly, one should refer to Laurasia here since the opening of the North Atlantic, which divided Laurasia into Eurasia and North America, began slightly later in the Palaeocene.

3 The highest peak is the French Mont Blanc with $4810 \mathrm{~m}$.

4 The highest altitudes of $2654 \mathrm{~m}$ are reached at the Slovakian Gerlach Peak.
} 
$53^{\circ} \mathrm{N}$ parallel to the axis of the North German Basin, which is a part of the European Permian Basin. When Meyer (1951) and Wiese (1962) noticed that certain variations of the vertical geomagnetic field component in the observatories of Wingst (latitude: $53^{\circ} 45^{\prime} \mathrm{N}$ ) and Niemegk (latitude: $52^{\circ} 04^{\prime} \mathrm{N}$ ) behaved in opposite directions, the idea of an underlying anomaly of electric conductivity in this location was born (Meyer 1951, H.-J. Linthe, pers. comm., 2014).

Schmucker (1959) gave a detailed description of the North German-Polish conductivity anomaly based on synchronous measurements along a $\mathrm{N}-\mathrm{S}$ profile by means of six portable variometers, devices with a sampling interval of $1 \mathrm{~min}$ and recording three orthogonal time-varying components of the magnetic field. Schmucker's work relied on interpretation of the magnetograms since sounding curves or induction arrows had not been invented at that time. Wiese (1962) continued such investigations to NE Germany and to several places in eastern Central and south-east Europe, presenting in this publication the first induction arrows of the type that is named now after him. ${ }^{5}$ Jankowski and Królikowski (1962) explored Poland and found that the German conductivity anomaly continues there. Pożaryski et al. (1965) gave a first overview on northern Central Europe summarising data from the three countries (i.e. Poland and both German states that were divided by the Iron Curtain at that time). It is interesting that up to that time our branch of research seemed to be rather connected to geomagnetic observation than to be a distinct section of sounding techniques, and magnetograms played an important role. Nevertheless, even then researchers were already aware (or at least guessed the existence) of all large-scale anomalies in the area considered here.

The impact of the invention of the induction arrow for the assessment of conductivity anomalies cannot be underestimated. Their illustrative behaviour, their direction perpendicular to the strike of a good conductor, the reversal of their real parts when crossing a good conductor (of course, both under the assumption that the well-conducting structure is more or less two-dimensional), and the depth information in their period dependence make them indispensable. Nevertheless, a map with a dense coverage of induction arrows can appear confusing. Hence, attempts have been made to refine the potential of such geomagnetic transfer functions for mapping purposes (which, however, would not be meaningful for some single stations or a single profile). Wybraniec et al. (1999) have subjected a collection of induction arrows to a two-dimensional Hilbert transform in order to transform from anomalous vertical fields to anomalous horizontal fields, which more clearly indicate the spatial (horizontal) distribution of anomalous currents, i.e. conductive zones. The images presented in their paper are definitely impressive and highly informative, and it represents the latest endeavour to give a qualitative overview of European conductivity structures, even if no attempt was made to interpret them. The approach of working with the anomalous horizontal magnetic field has been readopted and refined in a number of recent works (Habibian et al. 2010; Nowożyński 2012; Jozwiak 2012).

Returning to the North German conductivity anomaly, Schmucker (1959) explained its effect by a cylindrical conductor at a depth of $150 \mathrm{~km}$. A precondition for the insight of a shallower source of the anomaly was magnetotelluric measurements at shorter periods than accomplishable with "portable observatories". Geomagnetic pulsations were recorded and utilised one decade later (Vozoff and Swift 1968; Steveling 1973). At this time, researchers became aware of the important role of the sediments, which turned out to be far more conductive than assumed before (Steveling 1973). Broadband magnetotellurics have been performed in the 1990s by the German Federal Institute for Geosciences and Natural

\footnotetext{
5 Note that the first conception of an induction arrow is by Parkinson (1962). However, the Parkinson convention of the induction arrow has never been widely used in Central Europe.
} 
Resources, which covered the whole North German Basin with about two hundred stations on a dozen profiles (Hoffmann et al. 2008). Data allowed for a two-dimensional interpretation, and the models show a very good conductor with a resistivity of $<1 \Omega \mathrm{m}$ at ca. 200-2000 m depth throughout the basin. It has been identified as an aquifer of high salinity (Magri et al. 2005, 2008). Furthermore, a contrast between deeper sediments and the more resistive crystalline basement is visible in their models. Regionally, there are additional more resistive or highly conductive structures that have a geological interpretation, e.g., as salt diapirs and magmatic intrusions. Of special interest because of their implications for natural gas exploration are conductive layers at depths linked to the pre-Westphalian Carboniferous (ca. $6 \mathrm{~km}$ ): high-coalificated strata, encountered especially in the Emsland (the part of Germany close to the Dutch border), are potential source rocks for gas (Horejschi 2002; Hoffmann et al. 2008).

The most recent and largest scale research effort in this area came into being under the name EMTESZ (Electromagnetic investigation of the Trans-European Suture Zone) and, although its main part has been completed, some work lasts in its aftermath to date. In contrast to the German measurements of the 1990s, the new profiles were longer (wherever possible crossing onto the Precambrian Craton to some extent), and the measurements included the long-period range. Only in this way is there a chance to achieve information from beyond the basin sediments in both (laterally and depth) directions, in order to study the expected different types of basement and the transition zones, or tectonic borders, between them. Indeed, the prior view that especially the shallow saline aquifer would screen deeper structures from the electromagnetic source signals, and that the well-conducting sediments would absolutely dominate the magnetotelluric and geomagnetic transfer functions in this region, has been confirmed: A correlation between the pattern of real induction arrows and sediment depth (which reaches up to $8 \mathrm{~km}$ ) is demonstrated in Schäfer et al. (2011), and it is estimated that sediments cause more than $90 \%$ of the effect of the conductivity anomaly. This finding is somewhat disheartening since it means that the most famous anomaly of the continent has a rather profane reason, which has been known long beforehand due to more obvious branches of geosciences.

Figure 2 gives a simplified overview of the models obtained under the auspices of EMTESZ. All models show the shallow, widely and rather evenly spread conductor representing the basin sediments. Furthermore, differences in the resistive structures representing the crystalline basement of the Precambrian (to the NW) and of the Caledonian/ Variscan (Palaeozoic) are visible; the Precambrian one reaches deeper and has a tendency to be more resistive and generally more homogeneous. This correlates with findings from other domains of geophysics (as heat flow, e.g., Norden et al. 2008; Artemieva 2003 and earthquake tomography, e.g., Gregersen et al. 2002; Shomali et al. 2006) and very deep magnetotelluric soundings (Semenov and Jozwiak 2005; Pushkarev et al. 2007): Craton lithosphere is older, colder, thicker, and more consolidated than the one that has been attached subsequently and stepwise in Palaeozoic times.

A spatial coincidence of good conductors at mid-to-lower crustal depths (and for the STZ profile in the upper mantle) with the rim of the Precambrian Craton can be observed. According to Hoffmann et al. (2008) and Jozwiak (2012), the results of these magnetotelluric and geomagnetic studies suggest a correction of the hitherto assumed position of both the Caledonian Deformation Front and the Trans-European Fault (the proper suture between Baltica and Avalonia) more to the south. The nature of these conductors is assumed by all authors, i.e. Ernst et al. (2008), Smirnov and Pedersen (2009), and Schäfer et al. (2011), as carbon- and sulphide-rich black (alum) shales, since such rocks outcrop in southern Sweden and have been encountered in boreholes, e.g., close to Rügen Island. The 

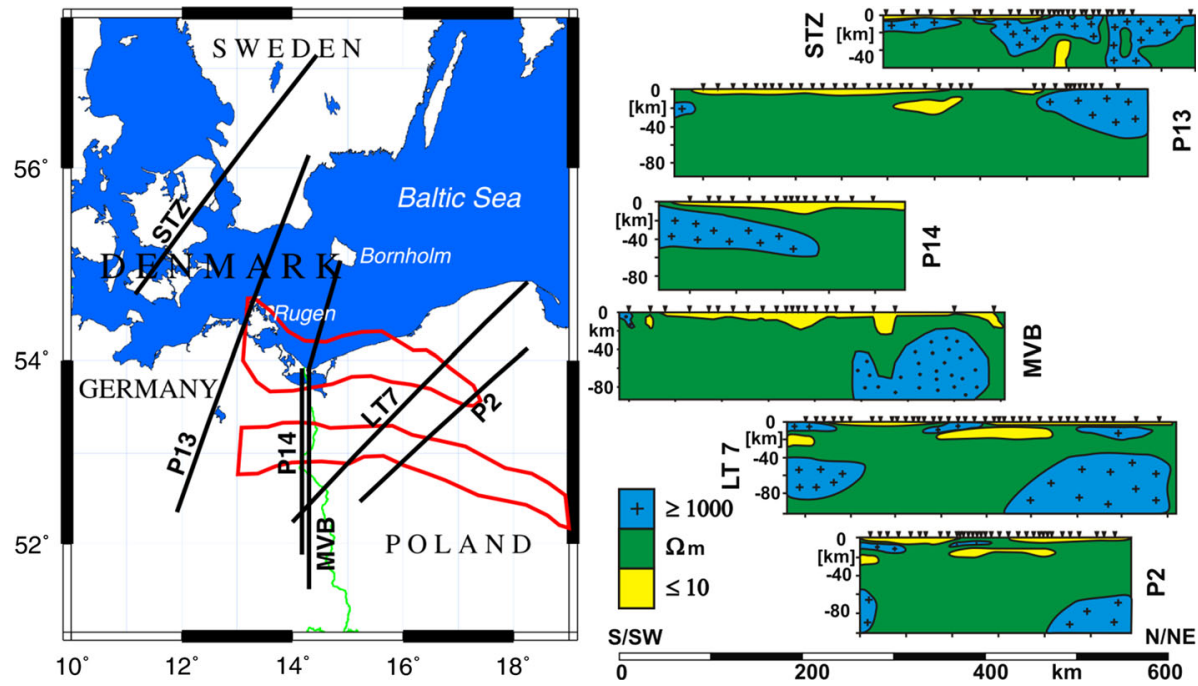

Fig. 2 Location map (left) and resistivity models (right) obtained during the investigation of the TransEuropean Suture Zone. Models simplified after Smirnov and Pedersen (2009)—STZ, Schäfer et al. (2011) $P 13, P 14$, Neska et al. (2008) - MVB (note that stations in the centre of this profile are identical to P14), Ernst et al. (2008) - LT7, P2. All models have the same lateral, depth, and resistivity scale. Areas in the map bordered by red lines mark zones where the anomalous horizontal magnetic field at $1800 \mathrm{~s}$ amounts to $\geq 1.5$ after Jozwiak (2012); this is limited to areas $\mathrm{E}$ of $13^{\circ}$ and $\mathrm{S}$ of $55^{\circ}$

role of graphitic layers for a low-friction thrust faulting during the plate collision is emphasised. A combination with saline fluids in such graphitised fault zones is discussed as well.

From a methodical point of view, it is worth highlighting the following: One of the profiles (B-B') reported in Hoffmann et al. (2008) covers the same area (i.e. it crosses Rügen Island and extends ca. $50 \mathrm{~km}$ into the mainland) that is traversed by profile P13 (Schäfer et al. 2011). Although this profile is rather short, its stations completely cover the local anomaly in the horizontal magnetic field (cf. Neska et al. 2008) that is caused by the mid-crustal conductor described for model P13 (Fig. 2). Comparison of models for both profiles [P13 and B-B', Fig. 3a)] reveals good agreement for that area from surface to the top of the mid-crustal conductor as it can be expected in terms of the equivalence principle. ${ }^{6}$ This consistency is noteworthy because the working approaches to both models were different in terms of measurement equipment, frequency range of the data, and both processing and inversion techniques.

Pushkarev et al. (2007) describe a study across the southernmost part of the Polish Caledonian-Precambrian transition zone through the Holy Cross Mountains. Here, outside the sedimentary basin, the model section shows well-conducting features that are expected and well interpretable from a geological point of view. These are a sedimentary trough delimited by two fault zones in front of the craton (Hakenberg and Świdrowska 1997).

\footnotetext{
6 The equivalence principle in one-dimensional magnetotellurics means that a layer with a certain conductivity and thickness produces the same effect in the data as a layer that is thinner, but more conductive; only the product of conductivity and thickness of a layer is well resolved. For this reason, the depth of a good conductor's upper boundary can usually be well determined and the depth of the lower boundary cannot as visible in Fig. 3a) (although this is, strictly speaking, a two-dimensional model).
} 
(a)

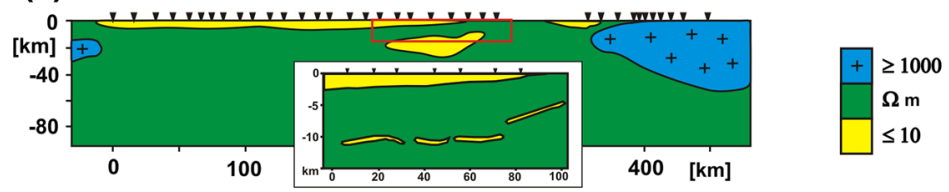

(b)

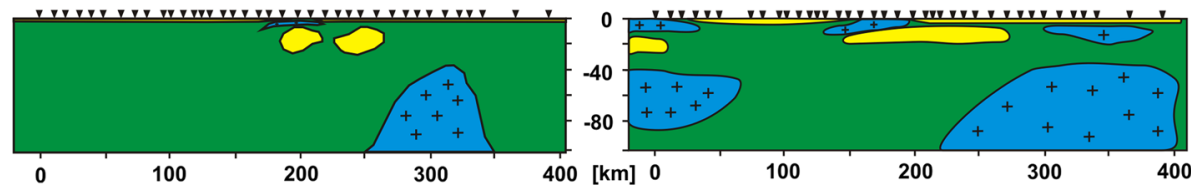

Fig. 3 Comparison of spatially coincident models after several authors. a P13 in the background (simplified after Schäfer et al. 2011, see Fig. 2 for position) and B-B' in the foreground (simplified after Hoffmann et al. 2008, its position within P13 is marked with a red frame) are similar in terms of position, depth, and upperboundary geometry of the mid-crustal conductor. b The main mid-crustal conductor for LT7 (see Fig. 2 for position) after Habibian et al. (2010, simplified, left-hand side) differs from the one after Ernst et al. (2008, simplified, right-hand side) by its twofold structure. See text for details

Overall, the Northern Central European conductivity anomalies can be explained in a consistent framework in spite of all difficulties in this area. Some minor uncertainties are pointed out.

(a) To the north of profile P14 (Schäfer et al. 2011), a good conductor (of an order of magnitude comparable to the mid-crustal ones in the surrounding models) is expected to appear, to be consistent with a horizontal magnetic field anomaly reported by Jozwiak (2012, Fig. 2). Such a conductor is found from inversion of induction arrows alone (model MVB, Neska et al. 2008, Fig. 2) using data of the same profile, but extending into the Baltic Sea and onto Bornholm Island. This demonstrates how important it is to have stations on both sides of an anomaly. Nevertheless, the absence of any well-conducting mid-crustal structure at the northern end of P14 leaves doubts about this part of the model. Further comparison of models P14 and MVB reveals that the high-resistive structure in the southern half of P14 is absent in the MVB model. In the latter model, this area shows resistivity values between 100 and $1000 \Omega \mathrm{m}$. Since P14 is based on inversion of all local transfer functions (TE mode, TM mode, and induction arrows) and MVB only on the latter, the first model should be regarded as more reliable in terms of this feature.

(b) The anomalous horizontal magnetic field shown in Jozwiak (2012), that reflects the results of Wybraniec et al. (1999), but with better resolution, suggests that the continuous mid-crustal conductor in the centre of the LT7 model (Fig. 2) should consist of two laterally distinguishable parts. Indeed, such a "double conductor" (i.e. a more detailed structure) appears for this profile when the horizontal magnetic data (i.e. inter-station transfer functions) are modelled jointly (Habibian et al. 2010, see Fig. 3b) for comparison of both models). Hence, one must question whether some overly intense smoothing has taken place during inversion of LT7 local transfer functions.

(c) The thickening of the conductive surface layer in the middle of P14 (Fig. 2) coincides spatially with the assumed position of the Variscan Deformation Front (Fig. 1). As pointed out in Schäfer et al. (2011), it is impossible to distinguish 
whether this feature reflects just a thickening of the sediments or a separate conductor linked to the tectonic border. This lack of resolution is a consequence of the screening effect of the highly conductive surface layer.

(d) A sort of "mantle conductor" (with a resistivity of about $30 \Omega \mathrm{m}$, therefore not distinguishable in Fig. 2) appears in the centre of models LT7 and P2 at 60-100 km depth (Ernst et al. 2008). High-frequency data above this region are three dimensional. This "mantle conductor" does not reappear in results of ongoing threedimensional inversions of these data (Slezak et al. 2014a, b). Hence, it may be concluded that this conductor could be an artefact due to two-dimensional inversion of partly three-dimensional data.

It is worthwhile highlighting that the electromagnetic image of the Trans-European Suture Zone has a counterpart in Western Europe: The Iapetus Suture in the Silurian-Devonian Caledonides of Scotland, Ireland, and Newfoundland (Hutton et al. 1977; Jones and Hutton 1979; Tauber et al. 2003; Rao et al. 2014) is characterised by a conductivity anomaly that was referred to as the Eskdalemuir anomaly (Osemeikhian and Everett 1968).

\section{The Variscides: Isolated Arrays, Anisotropy, and an Underestimated Anomaly}

As described in the previous and next sections, both for the NE of Central Europe and for the Carpathian region a more or less complete image of the conductivity structure could be derived. In contrast, with regard to magnetotelluric literature on the Variscides one cannot help but form the impression that a number of small-scale, independent regional studies exist next to each other without paying thorough attention to their neighbours. Therefore, in the opinion of the author conclusions achievable from a synopsis of the literature have not been drawn, and an attempt to compose a tectonic-based image of the region as a whole has not been made for the last two decades.

The most encouraging example of comprehensive compilation is rather old. The ERCEUGT-Group (1992) summarised resistivity models derived in previous work following the central segment of the European Geotraverse (Blundell et al. 1992) which transects all Variscan units in Germany. According to this compilation, it is possible to distinguish between these units by means of their electromagnetic images. Assessing details of the underlying original work are, however, beyond the scope of this paper.

More recent articles on the Variscan areas of Central Europe are, as mentioned, concerned with regional targets. In many cases, they suffer from the complexity of their data, that are either 3D or anisotropic or both, which did not allow for applying standard modelling methods at that time.

Leibecker et al. (2002) investigated the Rhenish Massif in the very west of Germany (Fig. 4). The target of this study was the putative Eifel Plume, which had been interpreted from images from seismic experiments (Raikes and Bonjer 1983), but could not be identified in the magnetotelluric data. Instead, the authors describe an anomaly in the $d_{D}$ element of the perturbation tensor (i.e. local magnetic field variations in E-W direction are enhanced in comparison with those of a reference station in a "normal" surrounding, Schmucker 1970b), a spatially rather constant, but strongly frequency-dependent regional strike direction, and a strong but also laterally constant splitting of MT phases. This is explained by means of a layered model with a layer in the upper crust containing 3D blocks, one somewhat anisotropic in the middle crust with the preferred direction $\mathrm{N} 45^{\circ} \mathrm{E}$, 


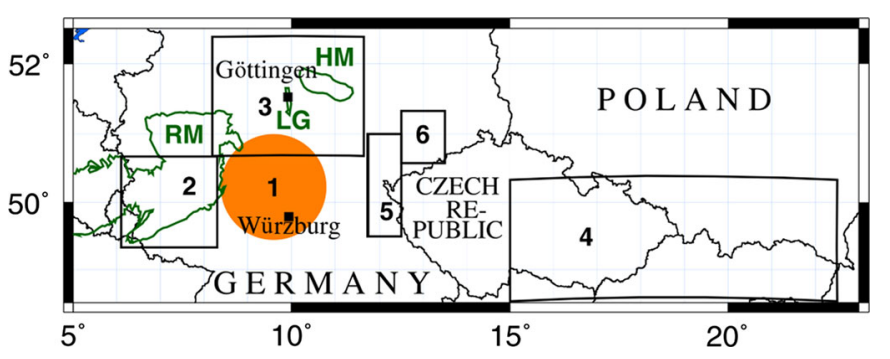

Fig. 4 Overview map for the Variscan tectonic unit. The circle (1) marks the location of significantly enhanced horizontal magnetic field variations at $1800 \mathrm{~s}$ after Wybraniec et al. (1999). Rectangulars denote study areas: 2 Leibecker et al. (2002), 3 Peter (1994), 4 Kováčiková et al. (2005), Červ et al. (2010), 5 Eisel and Haak (1999), Ritter et al. (1999), 6 Oettinger (1999). HM Harz Mountains, LG Leine-Graben (after Henningsen and Katzung 2002), RM Rhenish Massif

and one in the upper mantle with a strong anisotropy striking $\mathrm{N} 90^{\circ} \mathrm{E}$. The former is interpreted as fractures filled with hot, saliferous fluids (upper crust), or as interconnected network of graphite along microfractures following the Hercynian trend (middle crust). The phenomenon assigned to upper mantle depths is interpreted as anisotropy due to hydrogen diffusion in olivine crystals, which have a lattice-preferred orientation, where the $\alpha$-axis tends mainly west-east. The latter conduction mechanism is specified and quantified on an eastward extended data set in Gatzemeier and Moorkamp (2005). It is stated that the mentioned mechanism alone is insufficient to explain the observed effect in the data ${ }^{7}$ and that the orientation of olivine crystals could be related to relative motion between lithosphere and asthenosphere.

The mentioned extension of the data set stems from an older investigation (Peter 1994, Fig. 4) of a target named the Göttingen D-Anomaly. This name refers, again, to the $d_{D}$ element of the perturbation tensor, which is for sites close to Göttingen enhanced by almost $70 \%$ compared to stations ca. $100 \mathrm{~km} \mathrm{SE}$ and ca. $150 \mathrm{~km} \mathrm{~W}$ of Göttingen at a period of $600 \mathrm{~s}$. Peter (1994) shows that this is a large-scale anomaly and emphasises that its extent to the south reaches beyond the area mapped by the stations. Because of the threedimensionality of the data, a comprehensive model that explained all of the observations could not be obtained at the present time, but single modes could partly be fitted by a $\mathrm{N}-\mathrm{S}$ striking crustal structure with resistivities decreased by two orders of magnitudes in comparison to the surroundings. A possible relation to the Leine-Graben and to the Harz Mountains (Fig. 4) is mentioned (ibid.).

However, if one puts the location of both studies in relation to the maps by Wybraniec et al. (1999), a rather large anomaly becomes apparent. Its centre is clearly south of both Göttingen and the array used by Peter (1994); its southern margin reaches the town of Würzburg (Fig. 4). Since we understand such anomalies of the horizontal magnetic field variations as the secondary field of an anomalous current density at some depth, a notable conductivity anomaly should be expected there. Even if one is cautious about the exact shape of this phenomenon, it is rather suggestive to conclude that the "Göttingen"

\footnotetext{
${ }^{7}$ However, it must be admitted that newer work strengthens the plausibility of this mechanism at least partly: Joint inversion with seismic surface wave dispersion curves for anisotropic layering identified coparallel anisotropy directions in the asthenosphere, but not necessarily in the lithosphere (Roux et al. 2011). More recent work, using a novel approach adapted from medical imaging called Mutual Information, demonstrated that the electrical anisotropy can lie well within minerally defined bounds (Mandolesi and Jones 2014).
} 
anomaly does indeed extend much farther (possibly $\sim 200 \mathrm{~km}$ ) to the south and has been clearly underestimated so far.

The existence of such a first-order conductivity anomaly in the immediate neighbourhood would also raise doubts about the validity of the mantle anisotropy interpretation, which is still popular in newer small-scale studies of that region (Löwer et al. 2014). Given that (a) a good conductor outside a small array can influence all stations in nearly the same way, (b) the mechanism that could account for mantle anisotropy according to Gatzemeier and Moorkamp (2005) has been found to be insufficient (but see footnote 7), and (c) the induction arrow pattern shown in Gatzemeier and Moorkamp (2005) is, in fact, not homogeneous, I wonder if the concept of a deep anisotropic layer could not be relinquished in favour of a laterally inhomogeneous conductivity distribution. Thereby, the anisotropy interpretation would share the fate of another case study: Perhaps the most widely known example of lithospheric anisotropy is that seen in the Superior and Grenville Provinces of eastern Canada by Mareschal et al. (1995), which was compared to seismic anisotropy across the Grenville Front by Ji et al. (1996). However, a recent re-examination of data from the region by Adetunji et al. (2015) concluded that the spatially homogeneous anisotropy observed in the region of the Grenville Front is consistent with isotropic 2D structures.

Three-dimensionality of the data has also prohibited standard (i.e. at that time, two dimensional) modelling of the largest data set on the Variscan orogeny measured from the region of the Bohemian Massif to the Carpathians (Fig. 4, note that the eastern part of the measurement area leaves the Variscan and belongs to the Alpine basement). Kováčiková et al. (2005) and Červ et al. (2010) performed thin-sheet modelling and found wellconducting structures coinciding with the position and course of several known fault zones.

A small regional array at the German Continental Deep Drilling site (KTB, location on Fig. 4) is highlighted for its multidisciplinarity. Eisel and Haak (1999) modelled a conductive layer at $12 \mathrm{~km}$ depth with continuously increasing conductivity from south to north. Furthermore, they state anisotropy in the upper crust, which, however, is not only "intrinsically", but also "macroscopically" modelled. The latter possibility is favoured by evidence from two different fields. One is reflection seismics, which found several dipping reflectors with a strike coincident with the anisotropy direction. The other one is the borehole itself, which revealed these reflectors as "cataclastic shear zones filled with saline water and graphite and [...] thus excellent components for the electrical macro-anisotropic model". All findings fit in the tectonic model of the region, which is "a stacked and repeated pile of $[\ldots]$ rocks along graphitized shear zones" and "indicates a laterally distributed sequence of discrete vertical lamellae of high conductivity" (ibid.).

Ritter et al. (1999) also interpreted upper crustal high conductivity as graphitised shear zones but this time as horizontal shear planes. The study coincides spatially with the NW part of the previously considered KTB area. In terms of tectonics, the Münchberger Gneiss complex forms an allochthonous nappe, which was transported (and inverted) into its current position. The lubricating properties of graphite support the understanding of the high-conductive upper crustal layers as transport planes during the placement of that exotic nappe in its actual position.

Last but not least for the Variscan region, a study is highlighted that is possibly remembered more for its methodological than for its regional implications. Oettinger (1999) modelled the Saxonian Granulite Massif (location in Fig. 4) as a very resistive body (with resistivities up to $10,000 \Omega \mathrm{m}$ ) and found an extended high-conductive layer to the NE of it at ca. $18 \mathrm{~km}$ depth, which was interpreted as a graphitised thrust fault zone. This finding might be related to the mid-crustal layer described by Eisel and Haak (1999). 


\section{The Alpides: A Conductivity Anomaly Along a Mountain Range's Roots-Tracer of Orogeny?}

In this section, the Carpathian Mountains, the Pannonian Basin enclosed by them, and the Alps will be considered.

The Carpathians have been understood as host of a pronounced conductivity anomaly since the early 1970s (Rokityansky 1972) and experienced the vast number of ca. 1200 mostly geomagnetic measurements in the following two decades (Jankowski et al. 1985 and citations therein, Stănică et al. 1999 and citations therein, Zhamaletdinov 2005 and citations therein). As a result, the Carpathian anomaly is extraordinarily well mapped (Wybraniec et al. 1999; Nowożyński 2012). It resembles the shape of the mountain range and is present over the whole length of the arc $(1500 \mathrm{~km}$, Fig. 5). With this extent, it is of the same order of magnitude as the longest currently known mapped anomaly in the world-the North American Central Plains Conductivity Anomaly (Alabi et al. 1975). It seems to be laterally more continuous for the Western and Ukrainian parts than for the Romanian one. The centre of the anomaly coincides more or less (with deviations not larger than $20 \mathrm{~km}$ ) with the Pieniny Klippen Belt (Jankowski et al. 1985; Zhamaletdinov 2005; Fig. 5).

In spite of the large number of sites, many two-dimensional models of the area (Ernst et al. 1997; Ádám et al. 1997, Fig. 5) are not to modern standards. Reasons for this are the large distances between stations and that many of them were only geomagnetic ones and were measured with older equipment. This means that high-frequency data (at frequencies
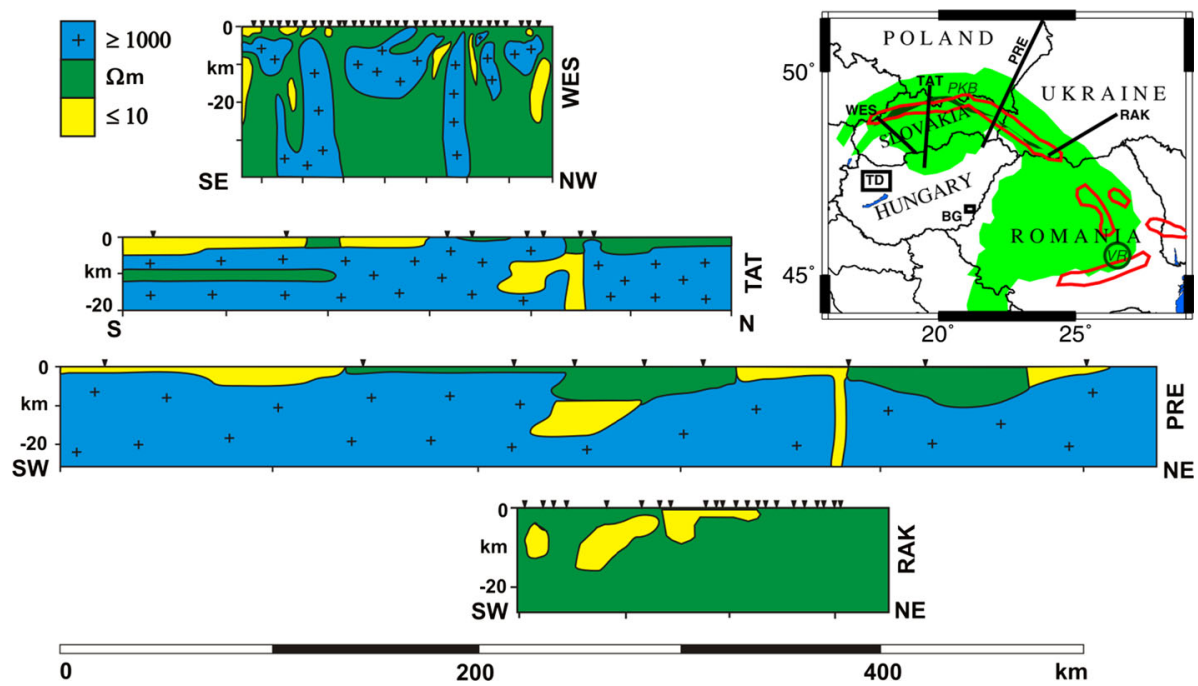

Fig. 5 Simplified 2D models after authors as given below and overview map (top right corner) for the Carpathian and Pannonian region. WES West Slovakian study (Bezák et al. 2014), TAT Tatra study (Ernst et al. 1997), PRE PREPAN study (Ádám et al. 1997), RAK Rakhiv profile (Gordienko et al. 2011). All models have the same lateral, depth, and resistivity scale, but note that RAK does not distinguish resistivity levels $>1000 \Omega \mathrm{m}$ in the original work. TD Transdanubian conductivity anomaly, $B G$ Békés Graben. Areas on the map bordered by red lines denote zones where the anomalous horizontal magnetic field at $1800 \mathrm{~s}$ amounts to $\geq 1.4$ after Nowożyński (2012). The Carpathian Mountains are highlighted in light green. PKB Pieniny Klippen Belt after Csontos and Vörös (2004), VR Vrancea Region after Sperner et al. (2001) 
$>1 \mathrm{~Hz}$ ) and magnetotelluric transfer functions (TE and TM mode) were not available for inversion. There is just one study showing a modern 2D model of the Carpathian anomaly, in which the anomaly appears beneath the very end of the profile (Bezák et al. 2014). The differences to older models in lateral resolution and information content for both shallow and deep ranges are stunning (Fig. 5). Nevertheless, crucial features are preserved between the models in spite of their distance and the different ways they have been obtained. These are the overall high crustal background resistivity, some basin structures, and especially the expected (from the horizontal magnetic anomaly) position, mid-crustal depth, and very low resistivity of the Carpathian anomaly that is prominent in all models. All models even show a dip of the anomaly to the south, although with varying slopes.

A study including several profiles across the Ukrainian Carpathians is reported by Gordienko et al. (2011). On the whole, they confirm the described image of the anomaly, even if it seems to penetrate deeper for some profiles (which, however, may be a product of the applied inversion algorithm) and that there is apparent a suspicious additional conductor at the very end of one profile. The best agreement to the anomaly in the Western Carpathians can be found for profile RAK (Fig. 5).

The nature of this anomaly has been very controversial. Jankowski et al. (1985), Ernst et al. (1997), and Jankowski et al. (2008) interpreted it as underthrusted cataclastic sediments with saline water in the pore space. Zhamaletdinov (2005) explained it as caused by graphite. Żytko (1997) also supports the graphite theory, showing that carbon-bearing rocks that would be capable of developing high conductivity under appropriate metamorphic conditions have been encountered in many places (outcrops and boreholes) of the Western Carpathians (this argument is also pointed out by Zhamaletdinov 2005). Nowadays current belief is that under reasonable assumptions neither of these conducting mechanisms (ionic or electronic conduction) alone would be able to produce such high conductances as observed. A possible combination of both (an idea that reaches back to Shankland et al. 1997) is acknowledged similarly as in the discussion of other mid-crustal conductors (e.g., Schäfer et al. 2011). It is worthwhile mentioning that partial melting is not only not included, but even excluded from the discourse on imaginable sources of the Carpathian anomaly with the argument of insufficient heat flow values in the region (Zhamaletdinov 2005). This contrasts with the situation that some conductivity anomalies beneath mountains of the same age are definitely thought to be caused by partial melts [e.g., in the Pyrenees (Pous et al. 1995), in the Himalaya (Pham et al. 1986, Li et al. 2003), and in the Pamir (Sass et al. 2014)].

Even if the available scientific material about the Carpathian anomaly is not ideal and often not presented in a way that can be called state of the art, it is comprehensive and significant enough to support a tectonic interpretation that is more distinct than the literature suggests. I will come back to this topic in the Discussion and Conclusions section.

Few publications exist that report regional induction studies in the Alps. This can be explained by the problems posed by topography in high mountains (Ádám et al. 1986) and by noise emitted by direct current (DC) railways on the Italian, i.e. southern, side of the Alps (Larsen et al. 1996). The available studies are insufficient to provide an electromagnetic image of these mountains as a whole. However, the presence of large-scale anomalies is indicated by real induction arrows at $1200 \mathrm{~s}$ that are consistent, e.g., over the German area north of the Alps (Gurk and Schnegg 2001 and citations therein). Basins surrounding the mountains and structures similar to the ones causing the Transdanubian conductivity anomaly (see below) are discussed as sources (Ádám et al. 2008). 
The Pannonian Basin spatially coincides approximately with Hungary. Its sedimentary fill is of Cenozoic age, and the underlying crystalline basement is quite heterogeneous as the geology of its many "inselbergs" shows (Csontos and Vörös 2004). It is characterised by a high heat flow of $100 \mathrm{~mW} / \mathrm{m}^{2}$ and a shallow asthenosphere, especially if compared to the one beneath the East European Craton, as inferred from magnetotellurics (Ádám et al. 1997). It is subjected to Neogene extensional forces that result in asthenosphere upwelling and Graben structures hidden in the sediments that become visible in resistivity and gravity models (Ádám and Wesztergom 2001; Ádám et al. 2005). The most pronounced structure of this type is beneath the Békés Graben (Fig. 5). It is also supported by seismic experiments (Posgay et al. 1995).

A conductivity anomaly expressis verbis is present in the Pannonian Basin as well: The Transdanubian conductivity anomaly (Fig. 5) is a high conductivity zone interpreted as caused by graphite (Ádám 2001). Although of small extent, it deserves attention due to its involvement in an interesting investigation that links conductivity of rocks with their properties relevant for seismics: Glover and Ádám (2008) show by means of laboratory experiments that carbon-bearing rock samples react on shearing on the one hand like a "predetermined breaking point" and on the other hand like a "deformable zone" under increasing pressure. Both processes are reflected in the resistivity of the sample due to growing interconnectivity of grain boundary carbon (through pressure and post-failure smearing processes) or due to interruption of such networks (at failure of the rock sample). Such a behaviour would have consequences on the interaction of carbon-bearing rocks with seismicity as they are observed in the area of the Transdanubian conductivity anomaly: first, the (lateral and depth) region of enhanced conductivity coincides with the source region of almost all seismic events from the local earthquake catalogue, practically all of them being rather weak. Second, larger earthquakes having their epicentres outside this region are more attenuated within this region than in comparable distances in other directions from the epicentre. Both effects are explained by the low shear strength of carbon-bearing rocks, which causes tectonic deformation to occur preferentially within them.

\section{Discussion and Conclusions}

In the following, important findings are summarised and recommendations for further research are given according to the preceding organisation of the work.

For the Precambrian-Caledonian area, a long history of research had to pass to let us understand that the North German conductivity anomaly is caused simply by the extraordinarily well-conducting basin sediments, at least to a very high degree, and that craton lithosphere is much more resistive and thicker than beneath Palaeozoic belts. Less obvious is the result that the zone between the suture and the deformation front of the Caledonian orogeny is characterised by a mid-crustal conductor. Furthermore, this conductor can be traced along the craton rim with such reliability that recommendations have been expressed to redraw this tectonic border according to the position of that conductor. This is a great achievement due to the electromagnetic induction methods. However, in the context of this area situations are encountered where the limitations of these methods have to be acknowledged, i.e. where the resolution of the fine structure of a conductor is in principle impossible beneath a shallow, screening, highly conducting layer. Therefore, optional future experiments designed to reveal the petrophysical nature of the mid-crustal 
conductor should take place in a region where it is more readily accessible for our methods, i.e. in a region not covered by sediments of such high conductance.

With regard to the German Variscan zone, it can be concluded that there are tentative hints on mid-crustal conductors that are eventually linked to tectonic boundaries as well. However, we are far from possessing an area-wide image of the conductivity distribution; hence, it is impossible to make robust conclusions about interpretation at this stage. As to the concept of mantle anisotropy that was suggested to parts of this region, the author believes that it is misleading and caused by the small size and isolated analysis of local arrays. To improve this situation, at least a consequent, common revision of all archival data is required, complemented by some new measurements in unmapped areas like at the German-Czech-Polish border. However, it would be more promising to cover the whole Variscan area south of the Permian Basin at once with not a necessarily dense but homogeneous array of long-period stations. This would reveal the overall conductivity distribution, especially with regard to the enigmatic anomaly south of Göttingen. The situation is more advanced for the Czech Republic since country-wide data sets do exist there that have already proven their significance in terms of geological structures. It would be desirable to subject them to full three-dimensional inversion to obtain models that can be compared to others.

With regard to the Carpathians, one may desire some modern magnetotelluric broadband data densely distributed on profiles (maybe three profiles crossing each the Western, Eastern, and Southern part of the mountain range), which are focused on the known position of the anomaly. However, such a modern project should differ from earlier ones not only by equipment and station layout, but also by the posed questions, or by the expectation which problems can be resolved by means of the obtained models. Such questions should concern the genesis of the Carpathians (the mapped shape of the anomaly leaves no doubts that it is linked to the mountain building), and they should be put on a solid plate-tectonic base. This has been done insufficiently in the reviewed literature: although the debate on ionic or electronic nature of the Carpathian anomaly is conducted with passion, the question of orogeny in terms of plate tectonics does not achieve the attention it deserves; in contrast, one can even still come across the term "geosyncline". 8 This is astonishing because the available results already suggest at least two ideas that aim directly at a plate-tectonical interpretation: first, does the different appearance of the horizontal magnetic anomaly (continuous in the Western and Eastern, interrupted in the Southern range) reflect the two terranes that compose this area? Or could the gaps in the anomaly in the very SE of the Carpathians be related with the fact that subduction is not terminated yet in this (the Vrancea) region? Second, can the south-dipping of the anomaly be correlated with the geometry of slabs of Eurasian oceanic crust that went down in this direction during subduction under the terranes? Further questions could be the following ones: can partial melting conclusively be excluded? Which development would the electrical properties of a carbon-rich rock undergo during low-grade, subduction-type (greenschist) metamorphism? If the Carpathian anomaly is (at least partly) of graphitic nature, is it something like an early stage of the mid-crustal conductors observed in the Caledonian and possibly in the Variscan Suture zones? If so, why are these conductors subhorizontal and the Carpathian one is rather subvertical? Investigations of this region can be regarded as favourable for two reasons: on the one hand, the rough conductivity distribution is known and can be expected to be two dimensional for a profile crossing the

\footnotetext{
8 The geosyncline theory was used to explain mountain building before the theory of plate tectonics became widely accepted by the geoscientific community during the 1960 s.
} 
mountains; this lowers the working effort. On the other hand, the rocks formed by the orogeny are (in contrast to the deeply buried Caledonides) accessible at surface. This promoted the development of theories on their genesis by other geoscientific disciplines, so their results are available and can be compared to resistivity models. Hence, it is even imaginable that magnetotellurics validates one of these theories and plays a decisive role for the future perception of the Carpathian orogeny.

An embarrassing situation for the magnetotelluric community about the Alpides is that the stage of investigation of the Alps itself by induction measurements is behind the times. Here, a large-scale research effort is definitely required. Scepticism about research in this region is sometimes expressed with regard to difficulties caused by DC railway noise. However, taking into account the Polish example - the country is covered by DC railways (Neska 2010) but a number of recent results could be presented in this review-such difficulties should be regarded as controllable in modern magnetotellurics.

Finally, I would like to return to the term "conductivity anomaly" and to its importance for the validation of magnetotelluric results. The material reviewed here is spatially relatively dense, i.e. research areas were often close to each other or even overlapping. This provides an opportunity to assess consistency of the models in terms of similarity of their main features to their neighbours or to earlier/later results from the same location. The conclusion after such a consideration is very simple: consistency between results is present where data sets contain a full (or at least the main part of an) anomaly, i.e. a reversal of real induction arrows or both slopes of a horizontal magnetic field anomaly. This is evident for (a) the profiles P13 and B-B' across Rügen Island (Fig. 3), (b) the profiles LT7 and P2 (Fig. 2), and (c) the profiles crossing the Carpathians (Fig. 5). In contrast, data sets that just indicate but not fully cover an anomaly (e.g. by long real induction arrows but without a reversal, or by just one slope of a horizontal magnetic field anomaly) can lead to results that raise doubts. This applies to the vanishing conductor on profile P14 (Sect. 2) and with respect to the Göttingen Anomaly in connection with the mantle anisotropy interpretation beneath the Rhenish Massif (Sect. 3). From a theoretical point of view, this is not unexpected. The uniqueness of the solution of the two-dimensional inverse problem in magnetotellurics, geomagnetic depth sounding, and magnetovariational sounding is bound to the completeness of data both along the axis perpendicular to the strike and over frequency to the points where a normal (one-dimensional) response is reached (Weidelt 1978; Gusarov 1981; Berdichevsky et al. 2000, all in Soyer 2002). Although it is impossible to meet these conditions in practice, the examples presented here show that it is worth trying at least to approach them. In particular, if one suspects that a data set covers just one side of a conductivity anomaly, it is strongly recommended to do everything possible to get data from the other side as well.

Acknowledgments I thank the Program Committee of the 22nd Electromagnetic Induction Workshop, held in Weimar, Germany, in August 2014 for inviting me to perform this review. I thank all colleagues who have provided me with literature, hints on literature, and helpful discussions, and who had time to answer my questions. The manuscript has been improved thanks to the editor Oliver Ritter, Alan Jones, and an anonymous reviewer. I have used Generic Mapping Tools to produce the maps in the figures. This work was supported within statutory activities No. 3841/E-41/S/2015 and by Grant No. 2011/01/B/ST10/07046 of the Ministry of Science and Higher Education of Poland.

Open Access This article is distributed under the terms of the Creative Commons Attribution 4.0 International License (http://creativecommons.org/licenses/by/4.0/), which permits unrestricted use, distribution, and reproduction in any medium, provided you give appropriate credit to the original 
author(s) and the source, provide a link to the Creative Commons license, and indicate if changes were made.

\section{References}

Ádám A (2001) Relation of the graphite and fluid bearing conducting dikes to the tectonics and seismicity (review on the Transdanubian crustal conductivity anomaly). Earth Planets Space 53:903-918

Ádám A, Wesztergom V (2001) An attempt to map the depth of the electrical asthenosphere by deep magnetotelluric measurements in the Pannonian Basin (Hungary). Acta Geol Hung 44:167-192

Ádám A, Szarka L, Verö J, Wallner Á, Gutdeutsch R (1986) Magnetotellurics (MT) in mountains-noise, topographic and crustal inhomogeneity effects. Phys Earth Planet Inter 42:165-177

Ádám A, Ernst T, Jankowski J, Jozwiak W, Hvozdara M, Szarka L, Wesztergom V, Logvinov I, Kulik S (1997) Electromagnetic induction profile (PREPAN95) from the East European Platform (EEP) to the Pannonian Basin. Acta Geodaetica et Geophysica Hungarica 32:203-223

Ádám A, Novák A, Szarka L (2005) Tectonic weak zones determined by magnetotellurics along the CEL-7 deep seismic profile. Acta Geodaetica et Geophysica Hungarica 40:413-430

Ádám A, Kohlbeck F, Novák A, Szarka L (2008) Interpretation of the deep magnetotelluric soundings along the Austrian part of the CELEBRATION-007 profile. Acta Geodaetica et Geophysica Hungarica 43:17-32

Adetunji AQ, Ferguson IJ, Jones AG (2015) Imaging the mantle lithosphere of the Precambrian Grenville Province: large-scale electrical resistivity structures. Geophys J Int 201(2):1040-1061

Alabi AO, Camfield PA, Gough DI (1975) The North American Central Plains Conductivity Anomaly. Geophys J Int 43(3):815-833

Artemieva IM (2003) Lithospheric structure, composition, and thermal regime of the East European Craton: implications for the subsidence of the Russian platform. Earth Planet Sci Lett 213:431-446

Berdichevsky MN, Dmitriev VI (2002) Magnetotellurics in the context of the theory of ill-posed problems (No. 11). SEG Books, Tulsa

Berdichevsky MN, Dmitriev VI, Mershchikova NA (2000) On the inverse problem in sounding using MT and MV data. MAX Press, Moscow

Berthelsen A (1992) From Precambrian to Variscan Europe. In: Blundell D, Freeman R, Mueller S (eds) A continent revealed: The European Geotraverse. Cambridge University Press, Cambridge, pp 153-163

Bezák V, Pek J, Voźar J, Bielik M, Voźar J (2014) Geoelectrical and geological structure of the crust in Western Slovakia. Studiae Geophysicae et Geodeticae 58:473-488

Blundell DJ, Freeman R, Mueller S (eds) (1992) A continent revealed: The European Geotraverse, structure and dynamic evolution. Cambridge University Press, Cambridge

Brasse H, Lezaeta P, Rath V, Schwalenberg K, Soyer W, Haak V (2002) The Bolivian Altiplano conductivity anomaly. J Geophys Res 107(B5):EPM-4

Červ V, Kováčiková S, Menvielle M, Pek J (2010) Thin sheet conductance models from geomagnetic induction data: application to induction anomalies at the transition from the Bohemian Massif to the West Carpathians. In: Ritter O, Weckmann U (eds) Proceedings of the 23rd Schmucker-Weidelt colloquium for electromagnetic depth research. Deutsche Geophysikalische Gesellschaft, Potsdam, pp 232-243

Csontos L, Vörös A (2004) Mesozoic plate tectonic reconstruction of the Carpathian region. Palaeogeogr Palaeoclimatol Palaeoecol 210:1-56

Eisel M, Haak V (1999) Macro-anisotropy of the electrical conductivity of the crust: a magnetotelluric study of the German Continental Deep Drilling site (KTB). Geophys J Int 136:109-122

ERCEUGT-Group (1992) An electrical resistivity crustal section from the Alps to the Baltic Sea (central segment of the EGT). Tectonophysics 207:123-139

Ernst T, Jankowski J, Semenov VYu, Adam A, Hvozdara M, Jóźwiak W, Lefeld J, Pawliszyn J, Szarka L, Westergom V (1997) Electromagnetic soundings across the Tatra Mountains. Acta Geophysica Polonica 45(1):33-44

Ernst T, Brasse H, Cerv V, Hoffmann N, Jankowski J, Jozwiak W, Kreutzmann A, Neska A, Palshin N, Pedersen LB, Smirnov M, Sokolova E, Varentsov IM (2008) Electromagnetic images of the deep structure of the Trans-European Suture Zone beneath Polish Pomerania. Geophys Res Lett 35:L15307

Gatzemeier A, Moorkamp M (2005) 3D modeling of electrical anisotropy from electromagnetic array data: hypothesis testing for different upper mantle conduction mechanisms. Phys Earth Planet Inter 149:225-242 
Gee DG, Stephenson RA (2006) The European Lithosphere: an introduction. Memoirs-Geological Society of London 32:1

Glover PWJ, Ádám A (2008) Correlation between crustal high conductivity zones and seismic activity and the role of carbon during shear deformation. J Geophys Res 113:B12210

Gordienko VV, Gordienko IV, Zavgorodnyaya OV, Kováčiková S, Logvinov IM, Tarasov VN, Usenko OV (2011) Ukrainskie Karpaty (geofizika, glubinnye processy). National Academy of Sciences of the Ukraine, Subbotin Institute of Geophysics, Logos (in Russian)

Gregersen S, Voss P, TOR-Working-Group (2002) Summary of project TOR: delineation of stepwise, sharp, deep lithosphere transition across Germany-Denmark-Sweden. Tectonophysics 360:61-73

Gurk M, Schnegg P-A (2001) Anomalous directional behavior of the real parts of the induction arrows in the Eastern Alps: tectonic and palaeogeographic implications. Ann Geofis 44:659-669

Gusarov AL (1981) On uniqueness of solution to inverse magnetotelluric problem for two-dimensional medium. In: Mathematical models in geophysics. Moscow University Publishers (in Russian)

Habibian BD, Brasse H, Oskooi B, Ernst T, Sokolova E, Varentsov I, EMTESZ Working Group (2010) The conductivity structure across the Trans-European Suture Zone from magnetotelluric and magnetovariational data modeling. Phys Earth Planet Inter 183:377-386

Hakenberg M, Świdrowska J (1997) Propagation of the south-eastern segment of the Polish Trough connected with bounding fault zones (from the Permian to the Late Jurassic). C R Acad Sci Paris 324(IIa):793-803

Henningsen D, Katzung G (2002) Einführung in die Geologie Deutschlands, Spektrum Akademischer. Verlag, Heidelberg (in German)

Hoffmann N, Hengesbach L, Friedrichs B, Brink H-J (2008) The contribution of magnetotellurics to an improved understanding of the North German Basin-review and new results. Zeitschrift der Deutschen Gesellschaft für Geowissenschaften 159(4):591-606

Horejschi L (2002) Magnetotellurik und Erdmagnetische Tiefensondierung in der Ems-Region, diploma thesis. Institut für Geophysik Westfälische Wilhelms-Universität, Münster (in German)

Hutton VRS, Sik JM, Gough DI (1977) Electrical conductivity and tectonics of Scotland. Nature 266:617-620

Jankowski J, Królikowski C (1962) O zmianach krótkookresowych ziemskiego pola magnetycznego na terenie Polski. Acta Geophysica Polonica 10(3):281-288 (in Polish)

Jankowski J, Tarłowski Z, Praus O, Pěčová J, Petr V (1985) The results of deep geomagnetic soundings in the West Carpathians. Geophys J R Astron Soc 80:561-574

Jankowski J, Jóźwiak W, Vozár J (2008) Arguments for ionic nature of the Carpathian electric conductivity anomaly. Acta Geophys 56(2):455-465

Ji S, Rondenay S, Mareschal M, Senechal G (1996) Obliquity between seismic and electrical anisotropies as a potential indicator of movement sense for ductile shear zones in the upper mantle. Geology 24:1033-1036

Jones AG, Hutton R (1979) A multi-station magnetotelluric study in southern Scotland-I. Fieldwork, data analysis and results. Geophys J Int 56(2):329-349

Jozwiak W (2012) Large-scale crustal conductivity pattern in Central Europe and its correlation to deep tectonic structures. Pure Appl Geophys 169:1737-1747

Jupp DLB, Vozoff K (1977) Two-dimensional magnetotelluric inversion. Geophys J R Astron Soc 50:333-352

Korja T (2007) How is the European lithosphere imaged by magnetotellurics? Surv Geophys 28:239-272

Kováčiková S, Červ V, Praus O (2005) Modelling of the conductance distribution at the Eastern margin of the European Hercynides. Studiae Geophysicae et Geodeticae 49:403-421

Larsen JC, Mackie RL, Manzella A, Fiordelisi A, Rieven S (1996) Robust smooth magnetotelluric transfer functions. Geophys J Int 124:801-819

Leibecker J, Gatzemeier A, Hönig M, Kuras O, Soyer W (2002) Evidence of electrical anisotropic structures in the lower crust and the upper mantle beneath the Rhenish Shield. Earth Planet Sci Lett 202:289-302

Li S, Unsworth MJ, Booker JR, Wei W, Tan H, Jones AG (2003) Partial melt or aqueous fluid in the midcrust of Southern Tibet? Constraints from INDEPTH magnetotelluric data. Geophys J Int 153(2):289-304

Löwer A, Junge A, Tietze K (2014) (An)isotropic 3D array magnetotelluric modeling of the south western Vogelsberg area, Abstract, 22nd Electromagnetic Induction Workshop, Weimar, Germany, August 25-30, 2014

Magri F, Bayer U, Jahnke Ch, Clausnitzer V, Diersch HJ, Fuhrman J, Möller P, Pekdeger A, Tesmer M, Voigt HJ (2005) Fluid-dynamics driving saline water in the North East German Basin. Int J Earth Sci 94(5-6):1056-1069 
Magri F, Bayer U, Tesmer M, Möller P, Pekdeger A (2008) Salinization problems in the NEGB: results from thermohaline simulations. Int J Earth Sci 97(5):1075-1085

Mandolesi E, Jones AG (2014) Magnetotelluric inversion based on mutual information. Geophys J Int 199:242-252

Mareschal M, Kellett RL, Kurtz RD, Ludden JA, Ji S, Bailey RC (1995) Archaean cratonic roots, mantle shear zones and deep electrical anisotropy. Nature 375:134-137

Meyer O (1951) Über eine besondere Art der erdmagnetischen Bay-Störungen. Dtsch Hydrogr Z 4(61) (in German)

Neska A (2010) Subsurface conductivity obtained from DC railway signal propagation with a dipole model. In: Proceedings of 23rd Schmucker-Weidelt-Colloquium for Electromagnetic Depth Research, Dtsch Geophys Ges, Potsdam, pp 244-251

Neska A, Schäfer A, Houpt L, Brasse H, EMTESZ WG (2008) From Precambrian to Variscan basement: magnetotellurics in the region of NW Poland, NE Germany and south Sweden across the Baltic Sea. In: Ritter O, Brasse H (eds) Protokoll zum 22. Kolloquium 'Elektromagnetische Tiefenforschung'. Dtsch Geophys Ges, Potsdam, pp 151-163

Norden B, Förster A, Balling N (2008) Heat Flow and lithospheric thermal regime in the Northeast German Basin. Tectonophysics 460:215-229

Nowożyński K (2012) Splines in the approximation of magnetic fields and their transforms at the Earth's surface. Geophys J Int 189:1369-1382

Oettinger G (1999) Magnetotellurische Messungen im sächsischen Granulitgebirge: Separation von Nutzund Störsignal und Verteilung der elektrischen Leitfähigkeit, PhD Thesis, Fachbereich Geowissenschaften der Freien Universität, Berlin (in German)

Osemeikhian JEA, Everett JE (1968) Anomalous magnetic variations in Southwestern Scotland. Geophys J R Astron Soc 15:361-366

Parkinson WD (1962) The influence of continents and oceans on geomagnetic variations. Geophys J Int 6(4):441-449

Peter C (1994) Elektrische Leitfähigkeitsmodelle der Erdkruste in Südhannover, Nordhessen und im westlichen Thüringen, abgeleitet aus der elektromagnetischen Induktion durch natürliche Felder, $\mathrm{PhD}$ Thesis, Universität Göttingen (in German)

Pham VN, Boyer D, Therme P, Yuan XCh, Li L, Jin GY (1986) Partial melting zones in the crust in southern Tibet from magnetotelluric results. Nature 319(6051):310-314

Posgay K, Bodoky T, Hegedüs E, Kovácsvölgyi S, Lenkey L, Szafián P, Takács E, Tímár Z, Varga G (1995) Asthenospheric structure beneath a Neogene basin in southeast Hungary. Tectonophysics 252:467-484

Pous J, Muñoz JA, Ledo JJ, Liesa M (1995) Partial melting of subducted continental lower crust in the Pyrenees. Journal of the Geological Society 152:217-220

Pożaryski W, Małkowski Z, Jankowski J (1965) Distribution of short-period geomagnetic variations related to tectonics in Central Europe. Rocz Pol Towarz Geol 35(1):97-102

Pushkarev PYu, Ernst T, Jankowski J, Jozwiak W, Lewandowski M, Nowozynski K, Semenov VYu (2007) Deep resistivity structure of the Trans-European Suture Zone in Central Poland. Geophys J Int 169:926-940

Raikes S, Bonjer KP (1983) Large-scale mantle heterogeneity beneath the Rhenish Massif and its vicinity from teleseismic P-residuals measurements, In: Plateau uplift. Springer, Berlin, pp 315-331

Rao CK, Jones AG, Moorkamp M, Weckmann U (2014) Implications for the lithospheric geometry of the Iapetus suture beneath Ireland based on electrical resistivity models from deep-probing magnetotellurics. Geophys J Int 198:737-759

Ritter O, Haak V, Rath V, Stein E, Stiller M (1999) Very high electrical conductivity beneath the Münchberg Gneiss area in Southern Germany: implications for horizontal transport along shear planes. Geophys J Int 139(1):161-170

Rokityansky II (1972) Anomaliya elektrovodimosti v zemnoy korye na Karpatakh. Izvestiya Akademii Nauk SSSR, Fizika Zemli 10:97-100 (in Russian)

Roux E, Moorkamp M, Jones AG, Bischoff M, Endrun B, Lebedev S, Meier T (2011) Joint inversion of long-period magnetotelluric data and surface-wave dispersion curves for anisotropic structure: application to data from Central Germany. Geophys Res Lett 38:L05304

Sass P, Ritter O, Ratschbacher L, Tympel J, Matiukov VE, Rybin AK, Batalev VY (2014) Resistivity structure underneath the Pamir and Southern Tian Shan. Geophys J Int 198:564-579

Schäfer A, Houpt L, Brasse H, Hoffmann N, EMTESZ Working Group (2011) The North German conductivity anomaly revisited. Geophys J Int 187:85-98

Schmucker U (1959) Erdmagnetische Tiefensondierung in Deutschland 1957/59: Magnetogramme und erste Auswertung. In: Abhandlungen der Akademie der Wissenschaften in Göttingen MathematischPhysikalische Klasse. Vandenhoeck \& Ruprecht, Göttingen (in German) 
Schmucker U (1970a) An introduction to induction anomalies. J Geomagn Geoelectr 22:9-33

Schmucker U (1970b) Anomalies of geomagnetic variations in the Southwestern United States. Univ. of California Press, Berkeley

Semenov VYu (2014) Results of crust and mantle soundings in central and northern Europe in the 21st century (review). Acta Geophys 62:1-22

Semenov VYu, Jozwiak W (2005) Estimation of the upper mantle electric conductance at the Polish Margin of the East European Platform. Izvestiya Phys Solid Earth 41(4):326-332

Shankland TJ, Duba AG, Mathez EA, Peach CL (1997) Increase of electrical conductivity with pressure as an indicator of conduction through a solid phase in midcrustal rocks. $\mathrm{J}$ Geophys Res 102(B7):14741-14750

Shomali H, Roberts RG, Pedersen LB, TOR-Working-Group (2006) Lithospheric structure of the Tornquist Zone resolved by non-linear P and S teleseismic tomography. Tectonophysics 416:133-149

Ślęzak K, Nowożyński K, Jóźwiak W, Martens D, Brasse H (2014a) Three-dimensional MT modeling for the Pomerania region in NW Poland. In: Proceedings of the 25th Schmucker-Weidelt-Colloquium for Electromagnetic Depth Research, Dtsch. Geophys Ges, Potsdam, Germany

Ślęzak K, Jóźwiak W, Nowożyński K, Hoffmann N, Brasse H (2014b) 3-D inversion of MT data to image the Variscan and Caledonian Deformation Fronts in NW Poland, Extended Abstract, 22nd Electromagnetic Induction Workshop, Weimar, Germany, August 25-30, 2014

Smirnov MY, Pedersen LB (2009) Magnetotelluric measurements across the Sorgenfrei-Tornquist Zone in southern Sweden and Denmark. Geophys J Int 176:443-456

Soyer W (2002) Analysis of geomagnetic variations in the Central and Southern Andes, PhD Thesis, Freie Universität Berlin, Germany

Sperner B, Lorenz F, Bonjer K, Hettel S, Müller B, Wenzel F (2001) Slab break-off-abrupt cut or gradual detachment? New insights from the Vrancea Region (SE Carpathians, Romania). Terra Nova 13:172-179

Stănică M, Stănică D, Marin-Furnică C (1999) The placement of the Trans-European Suture Zone on the Romanian territory by electromagnetic arguments. Earth Planets Space 51:1073-1078

Steveling E (1973) Erdmagnetische Tiefensondierung mit Variationen und Pulsationen im Einflussbereich der Norddeutschen Leitfähigkeitsanomalie, PhD Thesis, Universität Göttingen (in German)

Tauber S, Banks R, Ritter O, Weckmann U, Junge A (2003) A high-resolution magnetotelluric survey of the Iapetus suture zone in southwest Scotland. Geophys J Int 153:548-568

Van Wees JD, Stephenson RA, Ziegler PA, Bayer U, McCann T, Dadlez R, Gaupp R, Narkiewicz M, Bitzer F, Scheck M (2000) On the origin of the southern Permian Basin, Central Europe. Marine Pet Geol 17(1):43-59

Vozoff K, Swift CM (1968) Magneto-telluric measurements in the North German Basin. Geophys Prospect 16(4):454-473

Weidelt P (1978) Entwicklung und Erprobung eines Verfahrens zur Inversion zweidimensionaler Leitfähigkeits-strukturen in E-Polarisation, Habilitation treatise. Universität Göttingen, Göttingen (in German)

Wiese H (1962) Geomagnetische Tiefentellurik Teil II: Die Streichrichtung der Untergrundstrukturen des elektrischen Widerstandes, erschlossen aus geomagnetischen Variationen. Pure appl Geophys 52(1):83-103 (in German)

Wybraniec S, Jankowski J, Ernst T, Pecová J, Praus O (1999) A new method for presentation of induction vector distribution in Europe. Acta Geophysica Polonica 47(3):323-343

Zhamaletdinov A (2005) On electronically conductive nature of the Carpathian anomaly (geoelectric, geothermal, and geodynamic aspects). Publications of the Institute of Geophysics, Polish Academy of Sciences C-95(386):43-58

Żytko K (1997) Electrical conductivity anomaly of the Northern Carpathians and the deep structure of the orogen. Ann Soc Geol Pol 67:25-43 